\title{
Alternative Service Delivery Arrangements in Local Municipalities in Israel: A Case Study
}

\author{
Eti Sarig \\ The Political Science Department, The Open University, Raanana, Israel \\ Email: etisa@openu.ac.il
}

Received June $13^{\text {th }}, 2013$; revised July $14^{\text {th }}, 2013$; accepted July $29^{\text {th }}, 2013$

\begin{abstract}
Copyright (c) 2013 Eti Sarig. This is an open access article distributed under the Creative Commons Attribution License, which permits unrestricted use, distribution, and reproduction in any medium, provided the original work is properly cited.
\end{abstract}

\begin{abstract}
The adoption of alternative service delivery arrangements (ASDAs) is not a new phenomenon in Israeli local government. The current study is based on empirical quantitative research which examined the effect of economic and political factors on the scope of privatization and alternative service delivery arrangements (ASDAs) in local municipalities in Israel. The "economic constraint" model and the "political choice" model served as the theoretical framework for examining considerations underlying service privatization. The contribution of the current study to previous literature on ASDAs is in examining the effect of moderator variables on the scope of privatization (SOP). A study of 29 services in 106 local municipalities in Israel indicated that political factors have a dominant effect on the scope of privatization in local municipalities while the effect of economic factors is small and statistically insignificant. The following variables were found to have a statistically significant effect on the scope of privatization: number of employees, age of local municipality, employee costs and characteristics of the head of the local municipality.
\end{abstract}

Keywords: Alternative Service Delivery Arrangements; Service Delivery Arrangements; Municipal Service Delivery; Privatization; Out Sourcing; Contracting Out

\section{Introduction}

The emergence of "New Public Management" (NPM) and its faith in markets led to a search for alternative methods in the delivery of public services (Ohemeng \& Grant, 2008). ASDAs for social services currently characterize all welfare states, including Israel, and aim to minimize friction between government and the public by decreasing government activities. There is a growing tendency to accentuate the role of central government as a governing body rather than as a supplier of products and services. Concomitant with reduced government funds, this outlook has compelled local municipalities to seek ASDAs in the hope of enhancing utilization of the limited resources at their disposal by reducing costs, lowering the debt burden and increasing tax revenues. Indeed, the adoption of ASDAs by local municipalities increases in times of financial crisis and economic decline. In this study, ASDAs refer to privatization and the contracting out of local municipality services, or partnership with another public or private provider, or providing inducement for private or nonprofit production as alternatives to municipal provision and production - that is, every mode of service delivery that is not supplied by municipality employees alone.

Many studies deal with the economic considerations that compel local municipalities to adopt ASDAs (Morgan, Meyer, \& England, 1981; Poole, 1987; Savas, 1987; Stein, 1990; Wong, 1988; Melcher, 1994; Ben-Elia, 1996; Henig \& Holyoke, 2003 and others). However, these studies, as well as the current research, show that political considerations play a more dominant role in these decisions David, 1987; Del Bello, 1987; Higgins, 1989; Higgins \& Ian, 2002; Judd, 1988; Miranda, 1994; Sonenblum, Kirlin, \& Ries, 1977; Stein, 1990; Thompson, 1992; Wong, 1988; Warner \& Hebdon, 2001; Battaglio \& Legge, 2008; Shaw, 2003; Bel \& Fageda, 2008). Consequently, scholars in public administration have generally viewed the political context of governments as supplemental to economic factors (e.g., Morgan, Hirlinger, \& England, 1988). In spite of the claim that both political and fiscal constraints less clearly explain the consideration of privatization choices of local municipalities (Bel \& Fageda; 2009), political factors still matter when it comes to explaining patterns in local municipalities' adoption of ASDAs (Fernandez, Ryu, \& Brudney; 2008). The current research seeks to identify which factors (economic and political) lead to the adoption of ASDAs in Israeli municipalities and assisting them in offering a more efficient service in provision of social welfare services (education, welfare etc.).

Understanding these factors becomes more vital as the municipality's fiscal distress becomes greater and the municipality has to develop new creative thinking in service delivery. The importance of this research is growing because, to the best of my knowledge, this is the first study that examines the influence of moderator variables between the independent variables (economic and political) and the dependent variable (scope of privatization-SOP). Its significance is also due to the large number of independent variables examined in this research. The lack of research on this topic in Israel is the reason for using hypotheses from prior research in developed countries such as 
the USA as indicators of the extent to which ASDAs are adopted by local municipalities in Israel. Furthermore, in spite of the differences in governing patterns and public administration systems, local municipalities in Israel show similar economic management patterns and use management methods similar to those used in other developing and decentralized countries. In some cases this causes complicated and problematic functioning, because of incompatibility with government policy.

\section{Israel Local Municipalities-Background}

Israel is a unitary state, with only two levels of government: central and local. Its local government system is composed of three basic types of local municipality: 1) cities (municipalities that usually include more than 20,000 inhabitants); 2) local councils (smaller urban settlements); 3) regional councils (federations of villages, each having its own local village committee). The creation, boundary change and functioning of cities are subject to rules determined in the 1934 Municipal Ordinance ${ }^{1}$. The legal foundations of the Israeli local municipalities in the early 2000s are still British colonial. Israel in the early $2000 \mathrm{~s}$ is indeed to a degree centralized in the allocation of tasks (Razin, 2010: p. 64), for example, land use planning activities are largely subordinate to district and national committees controlled by the central state.

Unlike the USA and European countries, governance in Israel is characterized by considerable centralization and power in the hands of bureaucratic systems and by traditional management and governance systems that no longer suit the needs of the state, to the point that they constitute a barrier to the development of local municipalities (Nachmias et al., 1997: p. 7). Other researchers delineate the ramifications of over-centralization which characterizes the relationship between central government and local municipalities in Israel, a situation resulting in behavior by local municipalities that hinders their managerial effectiveness (e.g., Ben-Elia, 2004; Deri, 1999; Katz \& Mevorach, 1990; Razin, 2003). The involvement of central government plays a powerful role and affects local municipalities by means of government transfer of funds to the "extraordinary" budget of the local municipalities, and through government and municipal-governmental corporations (Hasson \& Hazan, 1997). The handling of matters such as building permits, development, city property taxes, fund transfers for project development, physical planning, ordinance plans, budgets and detailed monitoring of budget management, etc., all genuinely reflect the fact that local municipalities in Israel function as agents of the central government (Ben Elia, 2004, Blank, 2004). This state of affairs reduces the ability of local municipalities to take local issues into consideration, to formulate a local tax policy and to adopt an economic orientation that focuses on local needs and priorities. Moreover, there is an ambiguity in governmental laws. Formally, all authority is in central government but because of weak regulation, the local municipalities have a lot of autonomy, which they enforce. Since the 1970s, they have been more influenced by neoliberal approaches, that have led to a somewhat Thatcherist centralized form of neoliberalism in which privatization tends to bypass local municipalities rather than empowering them through the delegation of tasks and oversight responsibilities (Razin, 2010). The slowdown of the Israeli economy, in the 1970s and 1980s, encouraged municipal

${ }^{1}$ Ordinances and laws passed by the British colonial government (19181948). entrepreneurialism. The move from council-elected mayors towards directly elected ones in 1978 gave a further boost to local initiative. Economic stagnation and the fragmentation of political power, characterized by pressure groups which were growing in strength, and conflicting interests within the government, has been associated with the growing power of local municipalities, becoming engaged in a broader set of responsibilities that were no longer efficiently performed by the central state. The reliance by local municipalities on self-generated revenues, particularly on the profitable non-residential property tax, grew immensely in the mid-1980s, although the central state's general grant and earmarked transfers remained at close to 40 percent of local government revenues. However, decentralization has gradually given place, since the 1990s, to the recentralization of power in the hands of central government bureaucracies: the Ministry of Finance and legal establishment. The neoliberal discourse emphasizing privatization, public-private partnerships, competition, reduced public expenditure and a diminishing role for government in the economy, has not necessarily been in line with principles of decentralization and enhanced democratic institutions. Instead, steps to reform local municipalities included more top-down controls on the functioning of local municipalities, associated with the concentration of power in the hands of central state bureaucratic "gatekeepers", such as those at local authority level. Competition among local municipalities in Israel dictates the adoption of a strategy to gain a foothold in power loci vital for a municipality's existence, to protect itself against other municipalities seeking to seize control of its assets, thus preventing resources (businesses and residents) from moving to more attractive municipalities.

\section{Models Explaining the Adoption of ASDAs}

There are two main approaches in the literature dealing with the factors leading to the adoption of ASDAs. The first embraces the "economic constraint" model that views economic constraints as the key factor in local government policy decisions; the second espouses the "political choice" model that views political pressure as the primary factor in those decisions (Miranda, 1994; Wong, 1988; Bel \& Fageda, 2008). Studies examining local public policy suggests that decisions are made within a general and broad framework of structural constraints accompanied by economic constraints and political pressure and there is a tension and competition between them which affect policy-making at local government level (Higgins, 1989; Miranda, 1994; Pouder, 1996; Stein, 1990; Stevens, 1978; Wong, 1988 and others). This creates a wide range of alternative policies within the local government arena that can strengthen or weaken local policy. In certain cases local government policy is more the product of economic and technological constraints than political pressure (Stone, 1989), whereas in other instances political forces rather than economic forces take precedence in the process of adopting and implementing policy. Other researchers (Asher, 1983; Coyle, 1994; Horkin, Katz, \& Mevorach, 1998; Kinder, 1981; Kramer, 1983) have focused on voter behavior and political preferences. Stone (1989) concludes that municipal officials collaborate with those who can provide them with resources that they can utilize to achieve results congruent with the municipal policy they seek to promote. Additional studies view competition for capital as a factor that influences local government policy (Korosec, 1997; Boyne, 1998; Bel \& Fageda, 2007) and Bel \& Fageda (2009) add ideology as 
playing a major role for large cities. The above overview demonstrates that limitations on local government public policy can be political, economic, administrative, ideological, legal, statutory, or may derive from status gained through the control of resources (Torgovnik, 1994). Just as economic entities cannot disregard the politics involved in shaping policy, political pressure cannot ignore the existence of economic constraints. Even in cases in which public support for economic development is strong, political players and public entities must be taken into consideration.

\section{The "Economic Constraint" (EC) Model and Hypotheses}

According to the "economic constraint" (EC) model, economic considerations are primary to political. The foundations of the EC model can be found in Tiebout's (1956) "ideal world of fiscal equilibrium", as well as in Bish (1971), Wong (1988) and at length in Peterson's (1981) "City Limits". Fiscal stress of local municipalities and the desire to cut costs are the primary motivators behind the adoption of ASDAs (Wong, 1988; Korosec, 1997; Bel \& Fageda, 2007, 2009). The most important economic constraints shaping local government policy are competition from other local municipalities in the production and distribution of municipal services, and the competition between cities for residents and for companies in a market of public goods (Wong, 1988). Greater competitiveness improves the taxpayer's cost-benefit ratio, which in turn increases the attractiveness of a local municipality for residential and business purposes. Although there is international literature today which shows limited to no cost savings from privatization (Bel \& Fageda, 2009, 2007), fiscal constraints are used as an influencing factor (Feiock 2001) because local government, like any rational player, needs to ensure economic growth, and must promote programs that stem from considerations of economic benefit and avoid actions that may risk their fiscal welfare.

1. The greater the fiscal distress, the more likely the adoption of ASDAs. Municipalities are more likely to adopt ASDAs when they face severe fiscal distress, increased demand for services and heightened taxpayer opposition to tax increases. Melcher, 1994; Miranda (1994), Miller, 1987; Morgan et al., 1981; Poole, 1987; Korosec, 1997; Knox, 1988; Feiock, 2001; Bel \& Fageda, 2007, 2009 and others).

2. The greater the tax rate, the more likely the adoption of ASDAs. Income from tax as a proportion of total municipality income reflects the municipality's difficulties in raising income from taxes in its area. The municipality cannot raise local tax as it would like to do because this might encourage negative emigration of inhabitants and businesses. Therefore, when the income rate from taxes reaches its upper limit, this spurs the municipality to look for ways to cut its expenses. The assumption is, therefore, that the heavier the tax burden, the more inclined the municipality will be to adopt ASDAs (i.e. the greater the SOP). (Miranda, 1994; DelBello, 1987; Stein, 1990; Blake, 1988; Flinn, 1970; Knox, 1988; Higgins, 1989; Blackstone \& Hakim, 1997; Dye \& Garia, 1978, Coyle, 1994; Miller, 1987; Morgan, Hirlinger, \& England, 1988; Greene, 1999).

3. The greater the cost of public sector employees relative to those in the private sector, the more likely the adoption of ASDAs. Lower wages and benefits, low price bids to win contracts, hiring either temporary or part-time employees, reduced job security, utilizing human resources more efficiently (smaller staff) — all these factors reduce employee costs, which are a vital component of direct costs, and they are strong predictors of a local government management decision in favor of ASDAs (Miranda, 1994; Feiock, 2001; Reca \& Zieg, 1995; Knox, 1988; Stevens, 1978; Greene, 1999; Miller, 1987; Ferris, 1986; Morgan et al., 1988; Stein, 1990; Pouder, 1996).

4. The greater the degree of competition from other municipalities, the greater the likelihood of adoption of ASDAs. Competition between public and private service units can create efficiency. Samuel (1990) claims that the "organizational environment" within which the organization operates dictates the adoption of strategy intended to enhance the local municipality's relative power, to gain a foothold in power loci vital for its existence, and to protect itself against other municipalities seeking to seize control of its assets, thus preventing resources (businesses and residents) from moving to more attractive municipalities. In this case the likelihood of adopting ASDAs will increase.

5. The larger the availability of service providers ("vendors") within a geographic area, the greater the likelihood of the adoption of ASDAs. Large municipalities located in metropolitan areas enjoy the best of all worlds: (a) they have availability of alternative suppliers which serves as an incentive for the selected service provider to cut costs; (b) they can obtain lower bids in a competitive market; (c) they are able to replace contractors that do not fulfill requirements; (d) they can prevent suppliers from acting opportunistically, increasing transaction costs and inefficiencies. The larger the number of contractors willing to enter into a partnership with the municipality, the smaller the chances of monopolization (Reca \& Zieg, 1995; Knox, 1988; Blackstone \& Hakim, 1997; Miranda \& Lerner, 1995; Stein, 1990; Ferris, 1986; Foster, 1990; Bel \& Fageda, 2007).

6. The more positive the local municipality's previous privatization experience, the greater the adoption of ASDAs. Local municipalities gain an overall assessment of privatization with each application. With this in mind, positive past privatization experience (success) will encourage the adoption of similar measures in order to achieve similar results. Therefore, the adoption of ASDAs will be greater than in a local municipality with a negative experience. A community's historical characteristics may also prevent it from transferring functional responsibility areas to other entities for fear that such action might harm the municipality. To sum up, previous delivery mode is a strong predictor of the current service delivery arrangement (Korosec, 1997; Osborn \& Gaebler, 1992; Ferris \& Graddy, 1986; Stein, 1990; Lamothe et al., 2008).

\section{The "Political Choice" (PC) Model and Hypotheses}

The "political choice" (PC) model focuses on non-economic factors such as political institutions and processes and on political tradition (Wong, 1988). Kirlin, Ries, \& Sonenblum (1977) claim that a preference for local control of services reduces interest in adopting ASDAs that primarily involve external contractors, because local elected and appointed officials seek to maintain control over municipal service delivery. Political constraints such as coalition power relations and the desire to be reelected are primary characteristics of a political environment in which decisions are made at a local level (Peterson, 1981). Political pressure often succeeds in swaying decisions in such a way that they are ultimately based on non-economic motives 
- decisions that under more "favorable" political conditions would not be made. It must therefore be acknowledged that the decision to adopt ASDAs cannot ignore local politics, even if the decision is economically advantageous to the local municipality

1. The "older" the local municipality, the lower the adoption of ASDAs. In long-established municipalities the functional responsibility is bigger than in young municipalities. Political pressure on the municipality's leaders to continue providing the services which have been their responsibility so far explains, from a political perspective, why the age of the municipality influences the service provision. Still, the "older" the organization the greater its tendency to develop "bureaucratic" structural and functional characteristics. Therefore, we expected to get a negative correlation between the age of the municipality and ASDAs (Stein, 1990; Peterson, 1981; Dye \& Garcia, 1978; Miranda, 1994).

2. The greater the power of municipality employees (ME), the less likely the adoption of ASDAs. The ME are "vocal critics" of contracting out and other ASDAs, since they are those who stand to lose from the final outcome. They stand to incur the greatest damage when a decision is passed concerning the scope or content of local municipality activities. ME are among the most organized interest groups in local politics, and they impose "coercive isomorphism" in terms of pressure exerted by labor unions on local municipalities concerning ASDAs. A larger percentage of organized employees in a municipality breeds strong pressure on the municipality to provide municipal services on its own. Service provision through an external contractor is negatively related to the power of public service employee unions and to the size of the public service workforce (Coyle, 1994; Miranda, 1994; Pouder, 1996; Morgan et al., 1988; McIntosh \& Broderick, 1996; Stein, 1990; Korosec, 1997; Banfield, 1980; Bel \& Fageda, 2007; Foster, 1990; Reca \& Zieg, 1995; Femandez, Ryu, \& Brudney, 2008; Kelleher \& Yackee, 2009; Warner \& Hebdon, 2001; Soleil et al., 2007; Bel \& Fageda, 2007, 2009).

3. The greater the constituency demands for public jobs, the less likely the adoption of ASDAs. Local municipalities under pressure to fill vacant public service positions and/or contending with unemployment problems in the municipality will adopt fewer ASDAs because incumbents mayors will strive to maximize the employment opportunities at their disposal, particularly in cities with a large concentration of minorities or poor, two major groups that fall victim to job cutbacks resulting from privatization (Higgins, 1989) (Coyle, 1994; Miranda, 1994; Dye \& Garcia, 1978),

Three of the research variables: age of municipality (AOM), unemployment rate (UR), and number of employees (NOE) do not necessarily represent traditional political variables. But according to other research (Miranda, 1994), and given the environmental and structural conditions within which the local municipalities in Israel work, these variables are defined as political.

a) UR and AOM appear in the literature as political variables for an examination of the test for change. Higgins (1989), Stein (1990), Coyle (1994), Miranda (1994) and others refer to UR, and Peterson (1981), Stein (1990), Dye \& Garcia (1978) refer to AOM. The rationale behind these variables is that a high UR is considered a political consideration that weakens the motivation to privatize and vice versa. Regarding the AOM, the older it is, the wider its functional responsibility. This means that the municipality is obliged to provide a wide range of services and this weakens the motivation to privatize and vice versa. These arguments also apply in the Israeli case.

b) NOE: One of the traditional political variables in the literature is the percentage of municipal employees who are members of a trade union. In the USA, there is diversity in this variable (there are municipalities with a high rate of union employees and others with the opposite). In Israel this variable is constant. All municipal employees are union members. We thus used number of employees (NOE), a "less good" variable, as a substitute. The rationale behind using this variable, in full awareness of its comparative weakness, is that the NOE reflects their influence on the municipality's policy-making process.

4. The longer the term of incumbents, the lower the likelihood of adopting ASDAs. Incumbents who have served for long periods of time (several terms) are confident in their management and do not feel a need to change their policies or management strategies. The fact that they were elected again and succeeded in holding on to their position serves as proof-in their eyes - that their management is successful and that the voters agree with their policies (Coyle, 1994; Miranda, 1994). This reduces electoral pressure on them to adopt ASDAs.

5. Incumbent mayor who is politically weak, has seniority in the position and holds a negative view of privatization will adopt fewer ASDAs. The political power of the incumbents is important in contending with demands from pressure groups such as municipal employees and politically active citizens. From a social and political perspective, elected incumbents often have difficulty implementing ASDAs, despite evidence of cost savings as a result of private production of public services. If they believe that privatization may endanger their re-election chances, they will not be quick to "jump on the privatization bandwagon" (Thompson, 1992: p. 45). Incumbents seek to implement policies that "produce votes" and increase their chances of re-election especially incumbents who serve for long periods of time (Titheridge, 1998). For this reason, they will adopt fewer ASDAs (Coyle, 1994; Ferris \& Graddy, 1986; Ferris, 1986; Haque, 1996; Wong, 1988; Morgan, Meyer, \& England, 1981; Dye \& Garcia, 1978; Stein, 1990; Henig \& Holyoke, 2003).

\section{The Current Study-The Case of Israel-Empirical Analysis}

The analysis in this section provides an empirical test of the economic constraint (EC) and the political choice (PC) framework as applied to the adoption of ASDAs. Both quantitative and qualitative data were collected. Qualitative data were gathered through a questionnaire sent to incumbents and used for the following variables: prior privatization experience, employee power, demand for public service jobs, characteristics of incumbents, as well as for the dependent variable, scope of privatization (SOP). Quantitative and qualitative data were gathered for the following variables: employee power and demand for public service jobs. Quantitative data, obtained from various online sources, were used for all other variables. It is also important to note that there are factors such as size of municipality and type of service that were examined in a previous MA study and in Ben-Elia's (1990) research (the only two studies so far in Israel) that affect the adoption of ASDAs, but these were not examined in this research because of the desire to explore only factors not previously examined in Israel. 


\section{Research Model and Operational Measures}

The research variables (economic and political) will be followed by a discussion of the variable development and organization process, and description of the nominal and operational definitions of the variables and the methods used to measure them. To contend with the difficulty arising in the social sciences of demonstrating a direct relationship between the independent variables and the dependent variable, it was decided to add moderator variables in order to obtain a realistic picture of the situation in the local municipalities studied. To the best of our knowledge, this is to date the only study that uses moderator variables. It was also decided to add a control variable, population characteristics, in order to examine a possible affinity between local municipality population characteristics (social cluster) and local municipality scope of privatization. The aim of these adjustments was to reflect, insofar as possible, the characteristics of the study and the research population customary in such studies.

The variable "fiscal distress" was calculated by weighting the current budget over a three-year period in order to overcome possible distortions in the municipality budget caused by the proximity of an election year. Data were validated by examining differences in averages and standard deviations for three years of data for all other variables, showing the differences to be marginal and negligible.

The operational measures of the study variables were as follows: The dependent variable-local municipality scope of privatization (SOP). This variable reflects the total provision of services in the local municipalities. This is interval measured and included 29 of the most common services provided by local municipalities in Israel. These services were obtained from a list of services published by the Center for Local Government as well as from a typology of services adopted from Ben-Elia (1990). The service areas included: general management, financial management, sanitation, maintenance, water, development of infrastructures and operation of installations. To relate to every one of the 29 items in these areas, respondents were asked to answer a questionnaire indicating the arrangement for service delivery in their municipality - whether by full privatization (services provided by external providers only private or voluntary-coded 3), traditional (all services provided entirely by the municipal workers - coded 1) or mixed privatization (services provided by municipal workers and external providers inter municipal cooperation and mixed public and private or voluntary-coded 2). The overall SOP in each municipality was calculated as an index of 29 items of equal weight. The range of the S.O.P. is between 1.3 and 2.7 with a mean of 2.0 and S.D. of 0.26 . The higher the mean, the more the municipality tends to full privatization.

Independent variables (economic): Fiscal stress (FS) expresses the fiscal stress of the local municipality at a given time and it reflects the overall scope of the municipality's financial debts. The variable was calculated as the sum of three elements in the municipality budget: 1) current budget surplus/deficit as a percentage of the actual expenses of the municipality in the same year; 2) accumulated deficit as a percentage of the actual expenses of the municipality in the same year; 3 ) the burden of loans as a percentage of the actual expenses of the municipality in the same year. Note, a weighting of three years of fiscal stress was carried out to overcome the possible distortion in municipal budgets of an election, which begins a year before an election year (Rozevich, 1984, 1987). The level of FS of local municipalities ranges between $4 \%$ and $65.8 \%$, with a mean of $11.8 \%$ and a SD of $10 \%$. Examination of three-year differences between means and a standard deviation in other variables indicates marginal and negligible differences. This test is acceptable in the literature, e.g. the research of Osborn et al. (1981). Tax rate in the local municipality is defined operationally as the municipal property tax (arnona) as a percentage of all actual revenues from residential, industrial and commercial municipal property taxes collected by the local municipality Mean = 95.95, $\mathrm{SD}=10.49$. The data were collected from the annual fiscal report of the municipalities and not through a questionnaire. In Israel the arnona is $95 \%$ on average of the total municipal budget, therefore, this variable is a good reflection of the tax incomes of the municipality. Employee costs (EC) is defined nominally as salary and wage expenses in the local municipality, calculated as a percentage. The operational definition is the percentage of expenses on salary and wages in the municipal budget in a year. Mean $=34.55 \mathrm{SD}=7.37$ Competitive environment (CE) The variable was calculated as follows: we counted the number of local municipalities located in the same statistical region as the examined municipality (competing municipalities, CM; examined municipality, EM). The CM are divided into three groups according to their size (number of inhabitants) compared to the EM. The rating of the CM in the EM's region is calculated as the weighted sum of all CMs in the region: 1) the total of large $\mathrm{CMs}$ was weighted with the highest coefficient; 2) the total of CMs of the same size was weighted with a medium coefficient; 3) the total of small CMs was weighted with a coefficient of one (for further data please ask the author). The weighted coefficients thus reflected the level of their competition with the EM. For example, big CMs are greater competition for the EM than same size CMs. The data were collected from the Central Bureau of Statistics. The range of CMs is between $0-2216$ with a mean of 770.6 and SD 649.6. Service provider (SP) availability indicates the number of SP in the municipality. The variable was constructed as follows: for each municipality we counted the number of SPs in its region in the five most popular service fields in Israeli municipalities. The resulting number was weighted with the population size of the municipality. The data were collected from the up-to-date Yellow Pages of each municipality and not from the questionnaire. The variable was weighted to take into account population size in the municipality and to allow for a comparison between localities. Mean $=1.77, \mathrm{SD}=2.29$. Prior privatization experience (PPE) is defined as past experience in the privatization of local municipality services. The variable was used as a moderator variable and is comprised of quantitative and qualitative data. The quantitative data were collected from the Registrar of Companies, and they include the number of municipal companies and their age in every municipality. The qualitative data were collected through the questionnaire and they refer to three items: 1) PPE $0=$ no, $1=$ yes; 2 ) does the municipality learn from, and is it influenced by, the experience of similar municipalities? $0=$ no, $1=$ yes; 3 ) does the success of other similar municipalities in privatization of services encourage your municipality to try privatization too? $0=$ no, $1=$ yes. (Alpha Cronbach 0.64). The final variable of PPE was constructed in several stages: 1) subjective experience was calculated as the sum of the three items and the resulting variable was again encoded by its median to a dichotomous variable, $0=$ no experience, 1 = experience; 2 ) the objective variable was 
calculated as sum of seniority (veteran) in years of the municipal company and this variable was coded again into a new dichotomous variable according to its median, $0=$ no experience, 1 = experience; 3 ) finally, the sum of the two dichotomous variables (objective and subjective) was used to create the PPE variable. Mean $=0.48, \mathrm{SD}=0.50$.

Independent variables (political): municipality age (MA): is defined nominally as the age of the local municipality according to the founding date of the municipality. This variable is a political variable because of the city's functional responsibility (Stein, 1990; Peterson, 1981; Dye \& Garcia, 1978; Miranda, 1994). In a veteran municipality, the functional responsibility is greater than in the younger ones, and they have difficulties with their current delivery of expensive services. Stein (1990) show that contracting out delivery services is more widespread in metropolitan industrialized veteran areas because of the political stress on the incumbent to continue providing the same services for which they were previously responsible. This variable is a continuous measure that divides all municipalities included in the sample into two categories based on median age: young municipalities (under the median $=52$ ) and veteran municipalities (above the median), age bracket $4-134$ years, Mean $=58, \mathrm{SD}=31.6$. Employee power (EP) is defined as the ability of employees to influence local municipality decisions. The variable was based on subjective data which were collected through the questionnaire and was combined from two items: 1) do the municipality employees in your municipality have an influence on privatization decisions? $0=$ no, $1=$ yes 2 ) are the municipality employees a group that has an influence on the decision-making process of the municipality? $0=$ no, $1=$ yes (Alpha Cronbach between the two items is 0.5 ). The variable EP is the index of these two items. Mean $=1.46, \mathrm{SD}=0.70$. Number of employees (NOE) This variable expresses the power of the political pressure against privatization on the incumbent. Therefore the greater the NOE, the greater the pressure on the municipal leader not to use ASDAs. All local municipality employees in Israel are members of a labor union, therefore, their combined power has a strong influence on the incumbent mayor. The variable NOE is calculated as the number of municipality employees per capita (adjusting for pensioners). It was not feasible to combine the variables EP and NOE into one variable. The NOE is a political variable because it expresses political power over municipal decisions (see more explanation in $p 0.12$ ) NOE in the municipality was measured in time $\boldsymbol{t}=$ 2000 and the SOP in time $\boldsymbol{t}=2002$. Similar theoretical approaches have been used in Bel \& Fageda (2007). Mean = 454.6, $\mathrm{SD}=849.7$. It is customary in multiservice studies to use as an indicator the percentage of services contracted out. The method of measurement presented above is still a reflection relatively of the SOP in every local municipality. Demand for public service jobs (DPJ) is defined nominally as the demand for public service jobs in the municipality. The variable is measured using subjective data that serve as a measure of efforts invested by the incumbent to solve unemployment problems in the municipality. This variable is combined from two items that appeared in a questionnaire: 1) how much effort did the incumbent make to find a solution to the unemployment problem in his municipality? 2) what is the level of DPJ in the municipality? The two items were measured in an ordinal scale of five categories. Alpha Cronbach $=0.41$. Mean $=0.054, \mathrm{SD}=$ 0.21 . Unemployment rate (UR) is defined nominally as the UR in the municipality. This variable is a political variable because of the necessity for reduction in manpower which accompanies the adoption of ASDAs, particularly when contracting out. A high UR will therefore increase the pressure and the demands on incumbent to cope with the unemployment problem. Sensitivity to public demand is connected to the need to win elections through votes. The operational definition of this variable is the ratio between the municipal UR and population size. This variable is the objective data of UR in the municipality. Mean $=1.05, \mathrm{SD}=0.777$. Incumbent's power and privatization tendency (IPPT) is a moderator variable and defined as the power of the incumbent mayor to implement his privatization policy. The assumption is that if the incumbent is characterized as strong, he is able to overcome obstacles such as employee power and implement his privatization policy, whereas if he is characterized as weak he will find it difficult to overcome the employees' objections to privatization, which will affect SOP. The variable is composed of three variables: 1) political power; 2) government continuity; 3) incumbent's privatization tendency. Political power is made up of two objective measures: relative number of mandates received by the incumbent party and the percentage of votes for the incumbent in the election. The value of the two measures of power was combined and they were used as a new dichotomous variable (based on the median) whose categories are: $1=$ strong power, $0=$ weak power. The second variable, government continuity or incumbent seniority, reflects the number of terms the incumbent has served in office. This variable is recoded into a dichotomous variable (based on the median) $1=$ two or more terms, $0=$ one term only. The last two variables are based on objective data from the Ministry of the Interior. The third variable, incumbent privatization tendency, is a qualitative variable based on two items from the questionnaire: 1) is the foundation of the municipal company, in your opinion, considered as privatization? 1 = yes, $0=$ No. 2 ) is municipality management better in the traditional way (without privatization) or with privatization? $1=$ with privatization, $0=$ without privatization. The values of both items are combined to a dichotomous variable (based on the median) $0=$ tendency to traditional policy (without privatization), 1 = tendency to privatization. The values of the three dichotomous variables (political power, government continuity and incumbent privatization tendency) are combined and coded as a new dichotomous variable (by the median) $0=$ week power and privatization tendency, $1=$ strong power and privatization tendency. Mean of 0.47 and SD. of 0.5. Research Procedure: The questionnaires were sent by mail to all heads of the Jewish ${ }^{2}$ municipalities $(\mathrm{N}=180)$. One hundred and nineteen questionnaires were received; 13 questionnaires were rejected because of various problems. Therefore 106 questionnaires were used, representing $55 \%$ of all local municipalities in the target population (specifically, 39 cities, 46 local councils and 21 regional councils) $)^{3}$.

\section{Major Findings}

The research findings show that most of the local municipalities in Israel (above 50\%) deliver the following services through full privatization: guarding of institutions $81 \%$, accounting $70 \%$, garbage disposal $67 \%$, legal advice $61 \%$, infrastructure development $53 \%$ and pest control $50 \%$. In addition, over $50 \%$ of the

\footnotetext{
${ }^{2}$ The Arab local municipalities could not be included because of their refusal to answer the questionnaire.

${ }^{3}$ See more in introduction, pp. 2-3.
} 
local municipalities deliver the following services through a mixed privatization and traditional mode: maintenance of institutions $59 \%$, sewage maintenance $53 \%$, planning and public building $51 \%$, operation of installations $51 \%$, roads $50 \%$, culture $52 \%$ and leisure $56 \%$. Finally, most of the local municipalities in Israel deliver the following services in the traditional way: welfare $78 \%$, veterinary services $65 \%$ and bookkeeping $50 \%$. Theoretically we are dealing with four situations: 1 ) Positive previous experience/Strong incumbent; 2) Negative previous experience/Strong incumbent; 3) Positive previous experience/Weak incumbent $(\mathrm{N}=6)$; 4) Negative previous experience/Weak incumbent $(\mathrm{N}=3)$. However, through empirical testing two situations with small observations $(\mathrm{N}=6, \mathrm{~N}=3)$ were found; therefore, from the series of multiple regressions performed, the major findings of these two situations with large observations will be presented. In both situations there is a strong incumbent but previous experience of privatization is different: one is negative and the second positive (see Figure 1).

A general combined model examines the effect of both political and economic variables on SOP, in addition to the two moderator variables: PPE and IPPT.

The research hypothesis assumed that in situation (1) negative previous experience - the political variables would have a greater effect than the economic variables on SOP in the local municipality. When the incumbent is strong and previous privatization experience is positive (11), economic variables would have a stronger effect than political variables on SOP. Due to lack of research literature on ASDAs in Israel, this study was based on studies published in American and European literature (Melcher, 1994; Miller, 1987; Morgan et al., 1981; Poole, 1987; Wong, 1988; Korosec, 1997; Boyne, 1998; Bel \& Fageda, 2007, 2009; Wilkins, 2003 and others), which viewed fiscal pressures as the reason for the adoption of ASDAs by local municipalities. According to the assumptions of the economic model and based on literature published in the United States, incentives (such as change in land use) available to public officials may lead them to adopt a set of strategies that are "optimal" from their standpoint. Political leaders are constrained by economic arrangements, yet they can choose how to respond to the economic context as well as to other considerations, most notably what they need to do to be re-elected ${ }^{4}$. To this end they will take steps leading to local development that will prove their managerial and economic capabilities, concomitant with an awareness of the limitations of economic organizational forms (Elkin, 1987: p. 8). Hecht's study (2003) shows that a strong incumbent can make decisions and take measures to advance the municipality, while adhering to the goal of proper management and overcoming temporary situations involving changes within and among political parties. Hecht maintains that under the appropriate organizational, political, social and economic conditions, local leaders will take the opportunity to generate change

\begin{tabular}{lcc}
\hline & $\begin{array}{c}\text { Negative previous } \\
\text { experience }\end{array}$ & $\begin{array}{c}\text { Positive previous } \\
\text { experience }\end{array}$ \\
\hline Strong incumbent & $\begin{array}{c}\text { Hypothesis situation (1) } \\
\text { Political }>\text { economic }\end{array}$ & $\begin{array}{c}\text { Hypothesis situation (11) } \\
\text { Economic }>\text { political }\end{array}$ \\
\hline
\end{tabular}

Figure 1.

Research hypotheses in the two situations.

${ }^{4}$ Some municipal leaders adopt ASDAs simply on ideological grounds and this plays a major role for European and large cities (Bel \& Fageda, 2009). in the local municipality. Therefore, a good understanding of the factors which affect the adoption of ASDAs will help local political leaders to choose suitable tools for efficient municipal service delivery to its inhabitants.

Two multiple regressions were performed with the dependent variable "scope of privatization" (SOP) and all the independent variables, economic and political, using a double control method. The first regression was performed for the situation in which previous privatization experience is negative and the incumbent is strong (Table 1). The second regression was performed for the situation in which previous privatization experience is positive and the incumbent is strong (Table 2).

The findings indicate that when previous privatization experience is negative and the incumbent is strong (Table 1) the independent variables explain $24 \%$ of the variance in SOP (Adj $\mathrm{R}^{2}=0.24$ ). However, the model is not statistically significant, most likely due to the relatively small number of observations $(\mathrm{N}=30)$ and due to high correlations (co-linearity) between the following independent variables: number of employees and service provider availability $(r=0.79)$ and number of employees and previous privatization experience $(\mathrm{r}=0.83)$. It seems that the correlations above account for the gap between the adjusted- $R^{2}$ and the $R^{2}$. The results do not corroborate the research hypothesis but most of the empirical studies have low explanatory power (Bel \& Fageda, 2009). Nonetheless, the effect of political pressure on SOP is negative, reinforcing the hypothesis that when previous privatization experience is negative, the political variables have a stronger effect on SOP.

When previous privatization experience is positive and the incumbent is strong (Table 2) the effect of the political variables is stronger than that of the economic variables (two independent political variables were found to be statistically significant - age of municipality and number of employees, whereas none of the economic variables were found to be statistically significant). These findings are contrary to the research hypothesis which maintained that in a local municipality with positive previous privatization experience and a strong incumbent, the effect on SOP of the economic variables would be stronger than that of the political variables (beta of political variables $<$ beta of economic variables). The research findings in Table 1 indicate that the number of employees has a negative influence on SOP. In situation (2) = negative previous experience in privatization, the findings are in accordance with the research hypothesis, but in situation $(1)=$ positive previous experience in privatization, the NOE has a positive influence on the SOP, and these findings are contrary to the research hypothesis. The explanation of the unexpected findings in the Israeli context is that local municipalities that have positive previous experience in privatization tend towards more privatization through new employees. This is because privatization in Israeli local municipalities is carried out mainly through municipal companies. Consequently the municipality's employees encourage privatization because they expect to benefit from it through the better conditions and salaries they will get as municipal company employees.

Some of the unexpected findings can be attributed to the reliance on research hypotheses derived from studies conducted in the United States (because of lack of research in Israel). Razin (2003), claimed that the situation in Israel differs from that in other developed countries in which there is a considerable gap between formal local municipal frameworks and actual behavior patterns. This gap stems from the inability of government to adapt its behavior and cultural patterns to frequent reforms 
Table 1.

Multiple regression results when previous privatization experience is negative and incumbent is strong.

\begin{tabular}{|c|c|c|c|c|c|c|}
\hline \multirow{2}{*}{ Variable type } & \multirow[t]{2}{*}{ Variable name } & \multicolumn{2}{|c|}{ Unstandardized Coefficients } & \multicolumn{3}{|c|}{ Standardized coefficients } \\
\hline & & B & Std. Error & Beta & $\mathrm{t}$ & Sig. \\
\hline- & Constant & 1.008 & 1.127 & & 0.895 & 0.383 \\
\hline \multirow[t]{3}{*}{ Control variable } & Social cluster & 0.054 & 0.028 & 0.373 & 1.917 & 0.071 \\
\hline & Fiscal distress & -0.002 & 0.005 & -0.066 & -0.318 & 0.754 \\
\hline & Employee costs & 0.004 & 0.012 & 0.088 & 0.340 & 0.738 \\
\hline \multirow[t]{5}{*}{ Economic variables } & Tax rate & 0.002 & 0.009 & 0.052 & 0.229 & 0.822 \\
\hline & Competitive environment & 0.000 & 0.000 & 0.328 & 1.612 & 0.124 \\
\hline & Service provider availability & 0.330 & 0.115 & 0.577 & 2.873 & 0.010 \\
\hline & Municipality age & -0.002 & 0.002 & -0.212 & -0.973 & 0.344 \\
\hline & Unemployment rate & 4.119 & 3.724 & 0.289 & 1.106 & 0.283 \\
\hline \multirow{3}{*}{ Political variables } & Employee power & -0.020 & 0.092 & -0.047 & -0.216 & 0.831 \\
\hline & Demand for public service jobs & -0.076 & 0.075 & -0.201 & -1.011 & 0.325 \\
\hline & Number of employees & 0.000 & 0.000 & -0.174 & -0.704 & 0.491 \\
\hline
\end{tabular}

Note: $\mathrm{R}^{2}=0.530$ Adj $\mathrm{R}^{2}=0.242 \mathrm{Sig}=0.120 \mathrm{~N}=30$.

Table 2.

Multiple regression results when previous privatization experience is positive and incumbent is strong.

\begin{tabular}{|c|c|c|c|c|c|c|}
\hline \multirow{2}{*}{ Variable type } & \multirow[t]{2}{*}{ Variable name } & \multicolumn{2}{|c|}{ Unstandardized Coefficients } & \multicolumn{3}{|c|}{ Standardized coefficients } \\
\hline & & $\mathrm{B}$ & Std. Error & Beta & $\mathrm{t}$ & Sig. \\
\hline- & Constant & 2.66 & 0.839 & & 3.172 & 0.005 \\
\hline \multirow[t]{3}{*}{ Control variable } & Social cluster & 0.039 & 0.020 & 0.357 & 2.007 & 0.060 \\
\hline & Fiscal stress & 0.008 & 0.008 & 0.231 & 0.960 & 0.350 \\
\hline & Employee costs & -0.011 & 0.009 & -0.329 & -1.251 & 0.227 \\
\hline \multirow[t]{5}{*}{ Economic variables } & Tax rate & -0.003 & 0.007 & -0.060 & -0.345 & 0.734 \\
\hline & Competitive environment & 0.000 & 0.000 & -1.09 & -0.577 & 0.571 \\
\hline & Service provider availability & -0.010 & 0.018 & -0.108 & -0.569 & 0.576 \\
\hline & Municipality age & -0.055 & 0.002 & -0.712 & -2.999 & 0.008 \\
\hline & Unemployment rate & -2.772 & 2.067 & -0.256 & -1.341 & 0.197 \\
\hline \multirow[t]{3}{*}{ Political variables } & Employee power & -0.049 & 0.061 & -0.130 & -0.800 & 0.434 \\
\hline & Demand for public service jobs & 0.113 & 0.068 & 0.331 & 1.649 & 0.116 \\
\hline & Number of employees & 0.000 & 0.000 & 0.955 & 3.367 & 0.003 \\
\hline
\end{tabular}

Note: $\mathrm{R}^{2}=0.609 \operatorname{Adj} \mathrm{R}^{2}=0.370 \mathrm{Sig}=0.038, \mathrm{~N}=30$.

undertaken in the formal and organizational local municipality systems. In Israel, on the other hand, behavior patterns have changed considerably, yet the formal-administrative establishment has not sufficiently adapted to the new conditions. In addition, although Israeli local municipalities have an economicbusiness management orientation, similar to US municipalities, there are differences in the governing patterns, public admini- stration systems and types of problems facing local municipalities in Israel (as described on pp. 3-5). BenElia (1999) explains that the deficit budget conditions under which most local municipalities in Israel operate, that is, the cumulative result of both local management failures and central government policy, have created functioning difficulties and undermined the social and economic stability of local municipalities. A more realistic 
depiction is that local municipalities differ in the relative influence of the factors (economic or political) in accordance with their unique political and economic reality and the influence of interest groups on local policy (Mizrahi \& Medani, 2003). The findings confirm the centralization of central government and the dominance of the political factors which shape the political arena in Israel. In spite of the inability of government to adapt its behavior and cultural patterns to frequent reforms undertaken in the formal and organizational local municipal systems, the change in local municipality behavior patterns and the adoption of ASDAs represent market-based approaches to government, decentralization and an effort to increase efficiency and responsiveness of Israeli local municipalities.

Finally, empirical studies of local municipalities contracting for services have suggested that the political factors still matter when it comes to explaining patterns in local municipalities' adoption of ASDAs (Femandez, Ryu, \& Brudney, 2008; Heffetz \& Warner, 2004). The public service delivery and management in local municipalities in Europe addressed two major approaches to reforms: privatization, contracting-out, and "corporatization" of local services on the one hand, and public management reforms on the other (Kuhlmann, 2008). The direction of the course of privatization in local municipalities in the USA shows declining use of complete contracts and a dramatic rise in mixed public-private delivery (joint contracting) of city services (Warner \& Hefetz, 2008). One of the main reasons is the need to balance economic concerns with the political engagement of citizens (Hefetz \& Warner, 2007; Warner, 2009).

I accept the claim that fiscal and political constraints have been found to contribute to local service privatization in the studies of U.S cases published in the 1980s. Thus, in more recent work, Bel \& Fageda (2009) show that the relationship between privatization and these factors is less clear. But they also agree that the motivations for privatization in studies that consider a broad range of services (as has been done in this study) capture more accurately the influence of fiscal and political constraints on the privatization choices of local municipalities than do studies that examine just one service. Consequently, political factors still matter when it comes to explaining patterns in local municipality contracting and still help to account for variations in local municipality contracting as they did during the 1980 s (Fernandes, Ryu, \& Brudney, 2008, Megginson \& Netter, 2001). Also in this study we have learned about the general trend of Israeli local municipalities in adopting ASDAs and the conditions under which we have to consider other factors which might influence ASDAs, such as local municipality size, type of service and the particular institutional framework of government. The research findings show that not in every case of fiscal distress will the local municipality choose to adopt ASDAs. Moreover, in some cases, in spite of the expected saving or efficiency in service delivery, political factors and reelection considerations determine the mode of service delivery, in spite of the fiscal distress of Israeli municipalities.

This article not only emphasizes the political orientation in the decision-making process of the local municipalities, but also aids researchers and practitioners to understand the considerations involved in the decision-making process concerning the supply of municipal services.

\section{REFERENCES}

Asher, H. B. (1983). Voting behavior research in the 1980s: An exami- nation of some old and new problem areas. In A. W. Finifter (Ed.), Political science: The state of the discipline (pp. 339-388). Washington DC: American Political Science Association.

Banfield, E. C. (1980). America's cities enter a crucial decade. Chicago Tribune.

Battaglio, R., \& Legge, J. (2008). Citizen support for hospital privatization: A hierarchical cross-national analysis. Public Organization Review, 8, 17-36. doi:10.1007/s11115-007-0045-0

Bel, G., \& Fageda, X. (2007). Why do local governments privatise public services? A survey of empirical studies. Local Government Studies, 33, 517-534. doi:10.1080/03003930701417528

Bel, G., \& Fageda, X. (2008). Reforming the local public sector: Economics and politics in privatization of water and solid waste. Journal of Economic Policy Reform, 11, 45-65. doi:10.1080/17487870802134884

Bel, G., \& Fageda, X. (2009). Factors explaining local privatization: A meta-regression analysis. Public Choice, 139, 105-119. doi:10.1007/s11127-008-9381-z

Ben-Elia, N. (1990). Privatization of municipal services: Evaluation, planning, policy analysis. Hebrew: Center for Municipal Policy.

Ben-Elia, N. (1996). Organizational reorientation and learning in Israeli local government: The role of market type mechanisms. In N. BenElia (Ed.), Strategic changes and organizational reorientations in local government: A cross national perspective. London: Macmillan.

Ben-Elia, N. (1999). Government finance and the fiscal crisis in Israeli local authorities. Jerusalem: The Floersheimer Institute for Policy Studies (Hebrew).

Ben-Elia, N. (2004). The fourth generation: New local government in Israel. Jerusalem: The Floersheimer Institute for Policy Studies (Hebrew).

Blank, Y. (2004). The place of locality: Local government law, decentralization and unique space in Israel. Laws, 197-299 (Hebrew).

Bish, R. L. (1971). The public economy of metropolitan areas. Chicago, IL: Markham Rand McNally.

Blackstone, E. A., \& Hakim, S. (1997). Private ayes: A tale of four cities. American City \& County, 112, 4-12.

Boeker, W. (1997). Executive migration and strategic change: The effect of top manager movement on product-market entry. Administrative Science Quarterly, 42, 236-213. doi:10.2307/2393919

Boyne, G. A. (1998). Bureaucratic theory meets reality: Public choice and service contraction in US local government. Public Administration Review, 58, 474-484. doi:10.2307/977575

Coyle, C. (1994). Introduction. In C. Coyle (Ed.), Research in urban policy: Vol. 5: Local administration in the policy process: An international perspective (pp. 7-23). Greenwich, CT and London: JAI Press.

David, I. (1987). Privatization in America. Washington DC: Touche Ross.

Del Bello, A. (1987). Privatization as partnership: Refine, explore, extend. Financier, 11, 14-19.

Deri, D. (1999). Local government: De facto decentralization. In D. Nachmias, \& G. Menachem (Eds.), Public policy in Israel. Jerusalem: The Israel Democracy Institute (Hebrew).

Dye, T. R., \& Garcia, J. A. (1978). Structure, function, and policy in American cities. Urban Affairs Quarterly, 14, 103-123. doi: $10.1177 / 107808747801400105$

Elkin, S. L. (1987). City and regime in the American republic. Chicago, IL: University of Chicago.

Feiock, R. C. (2001). Service contracting and alternative service delivery: Theory and practice. In K. Liou (Ed.), Hand book of public management practice and reform (pp. 561-572). New York: Marcel Deker.

Femandez, J., Ryu, J. E., \& Brudney, J. L. (2008). Exploring variations in contracting for services among american local governments: Do politics still matter? American Review of Public Administration, 38, 439. doi:10.1177/0275074007311386

Ferris, J. M. (1986). The decision to contract out: An empirical analysis. Urban Affairs Quarterly, 22, 289-311. doi:10.1177/004208168602200206

Ferris, J. M., \& Graddy, E. (1986). Contracting out: For what? With whom? Public Administration Review, 46, 332-344. 
doi: $10.2307 / 976307$

Foster, G. (1990). HMG's tender trap. Management Today, 42-43.

Greene, J. D. (1999). Privatization popular among local government. Montana Business Quarterly, 37, 17-20.

Haque, S. M. (1996). Private service under challenge in the age of privatization. Governance: An International Journal of Policy and Administration, 9, 186-216. doi:10.1111/j.1468-0491.1996.tb00238.x

Hasson, S., \& Hazan, A. (1997). Municipal-private partnership: Opportunities and risks. Jerusalem: The Floersheimer Institute for Policy Studies (Hebrew).

Hecht, A. (2003). Local leadership leading to change: Another way is possible. Success in local authorities. Jerusalem: The Center for Social Policy Studies in Israel.

Hefetz, A., \& Warner, M. (2007). Beyond the market versus planning dichotomy: Understanding privatization and its reverse in US cities. Local Government Studies, 33, 555-572. doi: $10.1080 / 03003930701417585$

Hefetz, A., \& Warner, M. (2004). Privatization \& its reverse: Explaining the dynamics of the government contraction process. Public Administration Research and Theory, 14, 171-190. doi:10.1093/jopart/muh012

Heinelt, H., Razin, E., \& Zimmermann, K. (2010) Metropolitan governance - A new topic and an old debate.

Henig, J. R., \& Holyoke, T. T. (2003). Privatization, politics, and urban services: The political behavior of charter schools. Journal of Urban Affairs, 25, 37-54. doi:10.1111/1467-9906.00004

Higgins, R. (1989). Alternative service delivery in local government. In T. N. Clark, W. Lyons, \& M. R. Fitzgerald (Eds.), Research in urban policy: A research annual (pp. 93-108). Greenwich, CT: JAI Press.

Higgins, P., \& Ian, R. (2002). No room for manoeuvre: Does 'best value' provide a better deal for workers in UK local government? Society in Transition, 33, 266-277.

doi:10.1080/21528586.2002.10419065

Horkin, A., Katz, Y., \& Mevorach, B. (1998). Local hero: The election to local municipalities in Israel in the era of direct elections. Tel Aviv: Tel Aviv University (Hebrew).

Judd, D. R. (1988). The politics of American cities: Private power and public policy (3rd ed.). Glenview, IL: Scott, Foresman.

Katz, Y., \& Mevorach, B. (1990). Local autonomy in the age of local government privatization. Paper presented at the Ninth National Conference on Local Government and Administration, Jerusalem.

Kelleher, C. A., \& Yackee, S. W. (2009). A political consequence of contraction: Organized interests and state agency decision making. Journal of Public Administration Research and Theory, 19, 579-602.

Kinder, D. R. (1981). Presidents, prosperity and public opinion. Public Opinion Quarterly, 45, 1-21. doi:10.1086/268631

Kirlin, J., Ries, J., \& Sonenblum, S. (1977). Alternatives for delivering public services. Boulder, Col.: Westview Press.

Knox, P. L. (1988). Public-private cooperation: A review of experience in the US. Cities, 5, 340-346. doi:10.1016/0264-2751(88)90024-8

Korosec, R. (1997). Toward a new understanding of alternative service delivery: Why do local governments decide to contract out? Southeastern Political Review, 25, 325-338. doi:10.1111/j.1747-1346.1997.tb00842.x

Kramer, G. H. (1983). The ecological fallacy revisited: Aggregate versus individual-level findings on economics and elections, and sociotropic voting. American Political Science Review, 77, 92-111. doi:10.2307/1956013

Kuhlmann, S. (2008). Reforming local public services: Trends and effects in Germany and France. Public Management Review, 10, 573-596. doi:10.1080/14719030802264234

Lamothe, S., Meeyoung, L., \& Feiock, R. (2008). Examining local government service delivery arrangements over time. Urban Affairs Review, 44, 27-56. doi:10.1177/1078087408315801

McIntosh, I., \& Broderick, J. (1996). Neither one thing nor the other': Compulsory competitive tendering and southburgh cleansing services. Work, Employment \& Society, 10, 413-430.

Megginson, W. L., \& Better, J. M. (2001). From state to market: A survey of empirical studies on privatization. Journal of Economic Literature, 39, 321-389.

Melcher, R. (1994). Ironing the wrinkles out of privatization. Busi- nessweek, 122.

Miller, M. (1987). Doing more with less: Is privatization the answer? Ohio CPA Journal, 46, 57-58.

Miranda, R. A. (1994). Explaining the privatization decision among local governments in the United States. In C. Coyle (Ed.), Research in urban policy: Vol. 5: Local administration in the policy process: An international perspective (pp. 231-274). Greenwich, CT and London: JAI Press.

Miranda, R. A., \& Lerner, A. (1995). Bureaucracy, organizational redundancy, and the privatization of public services. Public Administration Review, 55, 193-200. doi:10.2307/977185

Mizrahi, S., \& Medani, A. (2003). Public policy and human rights. Politika-The Israeli Journal of Political Science and International Relations, 10, 14-20.

Morgan, D. R., Hirlinger, M. W., \& England, R. E. (1988). The decision to contract out city services: A further explanation. Western Political Quarterly, 41, 363-372. doi:10.2307/448543

Morgan, D. R., Meyer, M. W., \& England, R. E. (1981). Alternatives to municipal service delivery: A four-state comparison. Southern $R e$ view of Public Administration, 5, 184-199.

Nachmias, D., Danon-Kremzin, M., \& Yironi, A. (1997). Structural reform in Israel's public sector. Jerusalem: The Israel Democracy Institute (Hebrew).

Ohemeng, F. K., \& Grant, J. K. (2008). When markets fail to deliver: An examination of the privatization and de-privatization of water and wastewater services delivery in Hamilton, Canada. Canadian Public Administration, 51, 475-499. doi:10.1111/j.1754-7121.2008.00034.x

Osborn, R. N., Jauch, L. R., Martin, T. N., \& Glueck, W. F. (1981). The event of ceo succession, performance, and end environmental conditions. Academy of Management Journal, 24, 183-191. doi: $10.2307 / 255833$

Osborn, D., \& Gaebler, T. (1992) Reinventing Government: How the Entrepreneurial Spirit is Transforming the Public Sector. New York: Penguin Books.

Peterson, P. E. (1981). City limits. Chicago, IL: University of Chicago Press. doi:10.7208/chicago/9780226922645.001.0001

Poole, R. W. (1987). Privatizing city services: The efficiencies of the private sector. Vital Speeches of the Day, 53, 588-590.

Pouder, R. W. (1996). Privatizing services in local government: An empirical assessment of efficiency and institutional explanations. Public Administration Quarterly, 20, 103-126.

Razin, E. (2003). Local government reform in Israel: Between centralization and decentralization, between traditionalism and modernity. Jerusalem: The Floersheimer Institute for Policy Studies (Hebrew).

Reca, J. V., \& Zieg, K. C. (1995). Privatization: An analysis of contracting out of government-provided services. National Contract Management Journal, 26, 51-64.

Rozevich, S. (1984). A municipal business cycle in Israel. Quarter to an Economic, 31, 123. (Hebrew)

Rozevich, S. (1987). The aspect of the annual deficit of the local municipality. Quarter to an Economic, 33, 133. (Hebrew).

Samuel, Y. (1990). Organizations: Characteristics, structures and processes. Haifa: Zmora-Bitan and Haifa University Press (Hebrew).

Savas, E. S. (1987). Privatization: The key to better government. Chatham, NJ: Chatham House.

Shaw, E. (2003). Privatization by stealth? The Blair government and public-private partnerships in the National Health Service. Contemporary Politics, 9, 277-292. doi:10.1080/1356977032000146051

Soleil, C., Racine, C., \& P. Jalette. (2007). What have unions to do with reverse privatization? Journal of Collective Negotiations, 31, 303. doi:10.2190/CN.31.4.b

Sonenblum, S., Kirlin, J. J., \& Ries, J. C. (1977). How cities provide services: The effects of alternative structures. Cambridge, MA: Ballinger Press.

Stein, R. M. (1990). Urban alternatives: Public and private markets in the provision of local services. Pittsburgh, PA: University of Pittsburgh Press.

Stevens, B. J. (1978). Scale, market structure and the cost of refuse collection. Review of Economics and Statistics, 60, 438-448. doi: $10.2307 / 1924169$ 


\section{E. SARIG}

Stone, C. (1989). Regime politics: Governing Atlanta 1946-1988. Lawrence, KS: University of Kansas Press.

Thompson, S. (1992). Privatization-possibly positive politics. American City \& County, 107, 45-47.

Tiebout, C. M. (1956). A pure theory of local expenditures. Journal of Political Economy, 64, 416-424. doi:10.1086/257839

Titheridge, A. (1998). Innovation must be encouraged. Beacon Focus (LGC), 27, 29.

Torgovnik, E. (1994). The politics of urban planning policy in Israel. Jerusalem: Jerusalem Center for Public Affairs (Hebrew).

Warner, M. (2009). Civic government of market-based governance? The limits of privatization for rural local governments. Agriculture and Human Values, 26, 133-143. doi:10.1007/s10460-008-9181-6
Warner, M., \& Hebdon, R. (2001). Local government restructuring: Privatization and its alternatives. Journal of Policy Analysis and Management, 20, 315-336. doi:10.1002/pam.2027

Warner, M. E., \& Hefetz, A. (2008). Managing markets for public service: The role of mixed public-private delivery of city services. Public administration review, 68, 155-166. doi:10.1111/j.1540-6210.2007.00845.x

Wilkins, J. K. (2003). Conceptual and practical considerations in alternative service delivery. International Review of Administrative Sciences, 69, 173-189.

Wong, K. K. (1988). Economic constraint and political choice in urban policymaking. American Journal of Political Science, 32, 1-18. doi: $10.2307 / 2111307$ 